\title{
Endohyalina, the genus in the Physciaceae to accommodate the species of the Rinodina ericina-group
}

\author{
Mireia Giralt • Pieter P. G. van den Boom • John A. Elix
}

Received: 1 June 2009 /Revised: 10 August 2009 /Accepted: 12 August 2009/Published online: 16 September 2009

(C) German Mycological Society and Springer 2009

\begin{abstract}
The genus Endohyalina is characterized by crustose, autonomous, or obligately lichenicolous thalli, lecideine apothecia with a hymenium often more or less inspersed with oil droplets and a brown hypothecium, Bacidia-type asci, small Dirinaria-type ascospores developing with type B ontogeny, bacilliform conidia and containing diploicin as the major secondary metabolite. The genus is based on four species previously included in Rinodina $-R$. ericina $\mathrm{s}$. lat., $R$. insularis, $R$. interjecta and $R$. kalbii-and on two lichenicolous species from the Canary Islands described here as new, Endohyalina brandii and E. diederichii. The generic type, Endohyalina rappii, is reduced to synonymy with $E$. ericina whereas $E$. circumpallida is excluded from the genus and returned to Buellia s. lat. Except for the thalline growth form and the common lichenicolous habit, the diagnostic characters of Endohyalina are akin to those of Diploicia. New chemical data on Endohyalina insularis and E. kalbii are reported,
\end{abstract}

\section{Giralt}

Departament de Bioquímica i Biotecnologia (Àrea de Botànica), Facultat d"Enologia de Tarragona, Universitat Rovira i Virgili, Marcel·lí Domingo s/n,

43007 Tarragona, Spain

e-mail: mireia.giralt@urv.cat

P. P. G. van den Boom $(\bowtie)$

Arafura 16,

5691 JA Son, The Netherlands

e-mail: pvdboom@kpnmail.nl

e-mail: pvdboom@zonnet.nl

\section{J. A. Elix}

Research School of Chemistry, Australian National University, Building 33,

Canberra ACT 0200, Australia

e-mail: John.Elix@anu.edu.au and a simple method for determining the secondary chemistry of lichenicolous fungi is provided.

Keywords Generic recircumscription - Lichenicolous species $\cdot$ Lecanoromycetes $\cdot$ New combinations $\cdot$ New species

\section{Introduction}

All the species of the Rinodina ericina-group treated in the present paper are considered to be congeneric. They are characterized as autonomous lichens with a crustose thallus or obligately lichenicolous species with an epikapylic to endokapylic thallus, by containing diploicin and related substances (except for R. kalbii Giralt \& Matzer), an often more or less inspersed hymenium, and by having short bacilliform conidia. Further, all possess small Dirinariatype or similar ascospores, with pronounced internal wall thickenings (= rinodinoid ascospores), developing with type B ontogeny (where apical wall thickenings become distinct before the septum develops), Bacidia-type asci, lecideine apothecia and a brown hypothecium. Because of this combination of diagnostic characters, the generic position of these species has oscillated between Buellia s. lat. and Rinodina (Ach.) Gray.

Hafellner (1979) transferred Buellia saxatilis f. insularis Arnold into Rinodina on the base of its rinodinoid ascospores. Since then, many authors (e.g., Rambold et al. 1994; Giralt 2001; Mayrhofer and Lambauer 2004; Sheard 2004; Kaschik 2006) have discussed its generic position. The same ascospore character induced Kalb and Hafellner (1992) to describe $R$. madeirensis Kalb \& Hafellner as a Rinodina. Giralt and Matzer (1994) pointed out that the most reliable features to distinguish Buellia from Rinodina were those of the ascospores and retained R. kalbii and R. madeirensis in Rinodina. 
Subsequently, Giralt (2000) transferred Buellia ericina (Nyl.) Jatta to Rinodina for the same reason.

Giralt $(2000,2001)$ considered all the above species to be closely related and noted that they may belong to an undescribed genus in the Physciaceae, since none of the hitherto known crustose genera within this family possessed the same combination of characters (i.e., rinodinoid ascospores, type B ontogeny, Bacidia-type asci, lecideine apothecia and brown hypothecium), or to the placodioid genus Diploicia A. Massal. If this was so, Diploicia would have to be recircumscribed to include microlichen species with independent or lichenicolous habit (with crustose or endokapylic thalli). At the time, Giralt (2000) provisionally retained the species in Rinodina in the expectation that further taxa might well be found with the same diagnostic characters.

Subsequently, three additional species have been found to belong to the $R$. ericina-group, namely Buellia interjecta Müll. Arg., transferred to Rinodina by Mayrhofer et al. (1992) because of its rinodinoid ascospores, and the two lichenicolous species described in this paper.

In our opinion, the new data described in the present work confirm that the species of $R$. ericina-group are congeneric and should be accommodated in a genus other than Buellia s. lat. or Rinodina: either (1) a new genus of Physciaceae, or (2) the recircumscribed genus Diploicia.

However, when revising the 15 generic segregates of Buellia s. lat. erected by Marbach (2000), especially those containing diploicin, it became apparent that Endohyalina rappii (Imshaug ex R.C. Harris) Marbach could belong to the $R$. ericina-group. A detailed study of the type specimen and additional material established that E. rappii is conspecific with Rinodina ericina. As E. rappii is the type species of Endohyalina Marbach, the "new genus" in the Physciaceae [see (1) above] to include the species of the $R$. ericina-group already exists, namely the genus Endohyalina. Alternatives (1) and (2) are further discussed below.

Further alternative solutions to the problem include (3) to maintain the species of the $R$. ericina-group in the genus Rinodina, a solution discredited by the fact that molecular data clearly indicate that $R$. insularis belongs to the Buelliagroup rather than to the Physcia-group (Helms et al. 2003; Kaschik 2006; Wedin et al. 2002), or (4) to retain these species in the polyphyletic Buellia s. lat., an option which does not resolve the taxonomic position of these welldelimited taxa but obscures them in the heterogeneous assembly that comprises Buellia s. lat.

(1) The case for accommodating the species of the Rinodina ericina-group in the genus Endohyalina

A wide range of thalline forms is observed within the Physciaceae, where typically crustose, placodioid with distinct radiate-plicate marginal lobes, squamulose, foliose, umbilicate, and fruticose representatives are known. Apart from thallus morphology, microscopic characters of the asci, ascospores, hymenium, and conidia as well as chemistry have been used to segregate the genera of Physciaceae. Even after considering all these characters, the species of the $R$. ericina-group cannot be clearly assigned to any of the known genera of Physciaceae as they are currently defined.

The combination of a crustose (autonomous) or an epikapylic to endokapylic (lichenicolous) thallus, Dirinariatype ascospores with pronounced wall thickenings (rinodinoid ascospores), ascospore-ontogeny of type B, Bacidia-type asci, lecideine apothecia with a poorly developed proper exciple (aethalea-type), a brown hypothecium, bacilliform conidia, and the presence of diploicin (except for $R$. kalbii) exclude the species of the $R$. ericina-group from the following genera of Physciaceae:

1. The clearly delimited genus Buellia de Not. nom. cons. or Buellia s. str. (= Hafellia Kalb, H. Mayrhofer \& Scheid., cf. Gams 2004), with the generic type B. disciformis (Fr.) Mudd and all the species previously accommodated in Hafellia (and several other Buellia) are characterized by the typically large, Callispora-type ascospores with variable septation (from uniseptate to muriform) which develop with a particular ontogeny (distinct from types A and B) where subapical wall thickenings become distinct before the septum is inserted and the hymenium is strongly inspersed with oil droplets. In addition, they exhibit a very well-developed proper exciple which is not of the aethalea-type. Although some species contain diploicin (B. demutans (Stirt.) Zahlbr., B. capitis-regum W. A. Weber, H. desertica Marbach, B. dissa (Stirt.) Zahlbr., Buellia oidalea (Tuck.) Tuck, B. oidaliella A. Nordin, B. parastata (Nyl.) Zahlbr., B. procellarum A. Massal., B. pseudotetrapla (Pusswald) Elix, B. reginae Bungartz, and B. tetrapla (Nyl.) Müll. Arg.), their morphological characters readily distinguish them from the R. ericina-group.

2. The genera Rinodina, Rinodinella H. Mayrhofer \& Poelt and Mobergia H. Mayrhofer \& Sheard, with Lecanora-type asci, lecanorine apothecia, and a colorless hypothecium.

3. The genera Amandinea M. Choisy ex Scheid. \& H. Mayrhofer and Tetramelas Norman, with ascospores with slight internal wall thickenings or without thickenings (not rinodinoid) developing with type A ontogeny.

4. The placodioid genera Australiaena Matzer, H. Mayrhofer \& Elix and Dimelaena Norman, are separated from the $R$. ericina-group, the former by its lecanorine to biatorine apothecia, Lecanora-type asci, and filiform conidia; and the latter by its cryptoleca- 
norine apothecia and Buellia-type ascospores developing with ontogeny of type A. Another placodioid genus is the sterile (and for this reason not discussed here) Coscinocladium Kunze, included in the Physciaceae after molecular phylogenetic methods (Crespo et al. 2004). The genus Diploicia is discussed below.

5. Among the other genera of Physciaceae with an alternative thalline growth form-i.e., umbilicate, foliose or fruticose - the R. ericina-group only shows affinities with Dirinaria (Tuck) Clem. and Pyxine Fr. Both have Dirinaria-type ascospores (ontogeny of type B), but foliose thalli provided with organs of attachment, lack hymenial oil droplets, and have somewhat lecanorine apothecia (see Awasthi 1975).

6. Among the 15 crustose segregates of Buellia s. lat. erected by Marbach (2000), only the genera Sculptolumina Marbach and Cratiria Marbach may be distantly related to the $R$. ericina-group since they include at least some members with rinodinoid ascospores (see Marbach 2000, table 5/1: p. 42-44). Nevertheless, the generic types of Sculptolumina and Cratiria, [S. japonica (Tuck.) Marbach and Cratiria lauricassiae (Fée) Marbach, respectively] clearly differ from the $R$. ericina-group, the former by the large Mischoblastia-type ascospores, the presence of several quinones and anthraquinones, and the filiform conidia (Sheard et al. 2008; Giralt et al. 2009), and the latter by the triseptate ascospores, the presence of norstictic acid, and the alternative proper exciple which is paler in the central part (Marbach 2000; Nordin 2000; Giralt and Nordin 2002).

7. Currently, the genus Endohyalina includes two species, the generic type E. rappii and E. circumpallida (H. Magn.) Marbach (Marbach 2000). Our observations on the type of E. rappii have shown that it exhibits exactly the same features which are diagnostic of Rinodina ericina, and for this reason we consider the two taxa to be conspecific. The genus Endohyalina is recircumscribed here to accommodate the additional species of the $R$. ericina-group, but $E$. circumpallida is excluded from the genus and reverts to Buellia s. lat. Thus, we consider Endohyalina to include four previously known species, E. ericina s. lat. (= E. rappii; R. madeirensis), E. insularis, E. interjecta, and E. kalbii, and two new lichenicolous species described below (E. brandii and E. diederichii). Undoubtedly, the genus Endohyalina is related to the clade B, subclade III [family Pyxinaceae (Fr.) Stiz.)] as inferred by the genetic analyses of Helms et al. (2003), a clade which includes the genera Diploicia, Dirinaria, and Pyxine, all characterized by small Dirinaria-type ascospores with an ontogeny of type B, Bacidia-type asci, brown hypothecia, and lecideine to somewhat lecanorine apothecia (Awasthi 1975). They are separated from each other by alterna- tive growth forms of the thallus, being placodioid in Diploicia, and foliose in the latter two genera. The inclusion of the genus Diplotomma within this clade is doubtful (Crespo et al. 2004).

(2) The case for not accommodating the species of the Rinodina ericina-group in the genus Diploicia

The genus Diploicia includes three species, D. canescens (Dicks.) A. Massal., D. subcanescens R.G. Werner and D. africana (Tuck.) Matzer, H. Mayrhofer \& Rambold (Elix et al. 1988; Matzer et al. 1997; Kalb and Elix 2007). All three are non-lichenicolous, have large, thickly placodioid thalli with radiating marginal lobes and often form rosettes. Additional diagnostic characters include the lecideine apothecia, hymenia containing oil droplets, brown hypothecia, Bacidia-type asci, Dirinaria-type ascospores with type B ontogeny, and bacilliform conidia. Chemically, they contain the depsidone diploicin (and biosequentially-related substances) and atranorin in the cortex. Other lichen products reported for the genus include gyrophoric acid, secalonic acids $\mathrm{A}, \mathrm{B}, \mathrm{C}$, and an unknown secalonic acid derivative.

Thus, except for the placodioid thallus and the nonlichenicolous behavior, the diagnostic characters of Diploicia are consistent with those exhibited by the species of Endohyalina (= Rinodina ericina-group).

Nevertheless, Endohyalina is not considered synonym of Diploicia for the following reasons:

1. At present there is no genus within the Physciaceae which includes species with different thalline growth form [except for the polyphyletic Buellia s. lat. which includes species with both crustose and effigurate thalli with marginal lobes (e.g., Buellia cf. epigaea; Trinkaus and Mayrhofer 2000; Trinkaus et al. 2001)]. Indeed, authors have segregated genera solely on the basis of their different thalline growth forms [e.g., Buellia tesserata Körb. with a subeffigurate thallus and Dimelaena radiata (Tuck.) Müll. Arg. with a placodioid thallus, Rico et al. 2003; the foliose/subfruticose Anaptychia Körb. from the fruticose Tornabea Østh.].

2. Many genera in the Physciaceae are separated solely by one distinguishing character [e.g., Rinodinella from Rinodina, by the different ascospore-type; Hyperphyscia from Phaeophyscia Moberg, by the different conidia; Physcia (Schreb.) Michx from Phaeophyscia by the presence of atranorin in the cortex; Heterodermia from Physcia, by the different cortex anatomy; Dirinaria from Pyxine, by the different organs of attachment of the thallus].

Hence, we refrain from modifying the circumscription of the genus Diploicia, one of the better-delimited genera within the Physciaceae, to incorporate species which 
exhibit significant variations in thalline growth form and nutritional behavior.

\section{Materials and methods}

This study was based on herbarium material present in $\mathrm{BCN}$, G, NY, and the private herbaria of M. Brand, P. Diederich, K. Kalb, and the second author (P. van den Boom). Lichen morphology was examined by standard techniques using stereo and compound microscopes. The terminology used follows Poelt and Vězda (1984) for describing the thalline growth form of lichenicolous species, Rambold et al. (1994) for the asci, Scheidegger (1993) and Bungartz et al. (2004, 2007) for the proper exciple, and Giralt (2001) for the ascospore- and ontogeny-types.

Chemical constituents were identified by high performance liquid chromatography (HPLC) (Elix et al. 2003). The method used to detect the secondary substances present in the lichenicolous species is as follows: (1) analysis of a sample of the lichenicolous species including the thallus of the parasited host, and (2) analysis of the same thallus of the host but free of the lichenicolous species. Thus, the substances detected in (1) but absent from (2) belong to the lichenicolous species.

\section{Results}

\section{Emended description of the genus Endohyalina}

Endohyalina Marbach emend. Giralt, van den Boom \& Elix

Type species Endohyalina ericina (Nyl.) Giralt, van den Boom \& Elix [syn. Endohyalina rappii (Imshaug ex R.C. Harris) Marbach, see below]

Thallus lichenicolous, endokapylic to epikapylic on several crustose or fruticose hosts or autonomous and crustose; algae, when present, chlorococcoid. Apothecia lecideine, immersed to sessile, black, small. Excipulum proprium poorly developed, aethalea-type (Scheidegger 1993; Bungartz et al. 2007) with a dark outer part with hyphae with \pm swollen cells and a paler to colorless inner part with hyphae similar in structure and orientation to the paraphyses. Hymenium \pm inspersed with oil droplets or not. Hypothecium pale to dark brown. Asci Bacidia-type (Giralt and Matzer 1994; Giralt 2001). Apical cells of the paraphyses \pm enlarged, with brown caps. Ascospores brown at maturity but with the ends paler, always one-septate and small, ellipsoid or fusiform, with internal wall thickenings mostly of the Dirinaria-type, but also grading into the
Milvina-, Physconia- or Pachysporaria-type; ontogeny of type B (apical internal wall-thickenings appearing before the septum is inserted; Giralt 2001); torus present or not; spore surface smooth to microrugulate. Conidia bacilliform.

Chemistry Diploicin, fulgidin and isofulgidin; dechlorodiploicin, caloploicin, brialmontin 1 , atranorin, or secalonic acids present.

Ecology and distribution Lichenized thalli are corticolous or rarely lignicolous, usually growing on bark of coniferous trees (Juniperus, Pinus) and of phorophytes with rough bark (Calluna, Erica, Tamarix). Lichenicolous thalli grow on crustose (Aspicilia, Lecanora) or fruticose (Ramalina) species present on silicicolous substrata. The genus is predominantly oceanic and mainly restricted to the Temperate European Atlantic regions and to the Mediterranean and Macaronesian regions. It is particularly well represented in coastal habitats. The type species, Endohyalina ericina, extends from these areas south to the Atlantic subtropical (Alabama, Florida) and tropical (Brazil) regions where it usually occurs on mangroves, whilst E. insularis, the most widely distributed species of the genus, shows a distribution similar to that of Diploicia canescens (see Kalb and Elix 2007).

Discussion The species included in the here-recircumscribed genus Endohyalina can be segregated in three different groups. The group including the type species E. ericina and $E$. diederichii, characterized by a whitish thallus, composed of verrucae or granules, a tinspersed hymenium, weakly enlarged apical cells of the paraphyses and fusiform ascospores; the group including E. brandii, E. insularis and E. interjecta, with a brown thallus (when present), composed of subsquamulose areolae, an hymenium lacking oil droplets, strongly enlarged apical cells of the paraphyses and ellipsoid ascospores. Finally, E. kalbii differs from both groups by the continuous, ochraceous thallus lacking secondary metabolites and the presence of secalonic acids in the proper exciple.

\section{Key to the species of Endohyalina}

1 Thallus autonomous, not lichenicolous . . . . . . . . 2

2 Thallus whitish, composed of discrete to continuous verrucae; hymenium inspersed with few to numerous oil droplets; ascospores fusiform, 10-18×(4.5-)

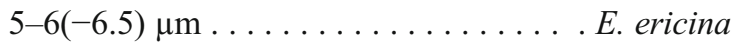

2* Thallus ochraceous or brown; hymenium without oil droplets; ascospores ellipsoid . . . . . . . 3

3 Thallus ochraceous, continuous, lacking crystals (polarized light); ascospores 11-16×(5-)6-8 $\mu \mathrm{m}$, 
with rounded lumina (Pachysporaria-type); proper exciple $\mathrm{K}+$ yellow (secalonic acids) . . .

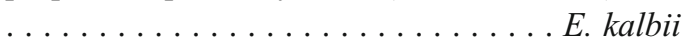

$3^{*}$ Thallus brown, discontinuous, composed of subsquamulose areolae, containing crystals (polarized light); ascospores 10-12(-14) ×4.5-5.5 $\mu \mathrm{m}$, not of Pachysporaria-type; proper exciple $\mathrm{K}-\ldots \ldots \ldots$. . . . . . . . E interjecta

$1^{*}$ Thallus obligately lichenicolous . . . . . . . . 4

4 On Ramalina; hymenium inspersed with abundant oil droplets; thallus absent or composed of discrete, minute, whitish to pale grayish granules; apical cells of the paraphyses up to $4 \mu \mathrm{m}$ diam.; ascospores fusiform ................. diederichii

4* Not on Ramalina; hymenium not inspersed; thallus absent or when present not as above, brown; apical cells of the paraphyses 5-6 $\mu \mathrm{m}$ diam.; ascospores ellipsoid. . . ..................

5 On Lecanora rupicola agg.; thallus commonly absent; apothecia immersed in the thallus of the host to adnate, up to $0.7 \mathrm{~mm}$ diam.; ascospores 11-17×5.5-9 $\mu \mathrm{m}$; hypothecium dark brown . . .................... E. insularis

5* On Aspicilia intermutans; thallus present; apothecia sessile, up to $0.3 \mathrm{~mm}$ diam.; ascospores 11-13(-14) $\times 6-7(-7.5) \mu \mathrm{m}$; hypothecium pale reddish brown ............... E. brandii

\section{The species}

Endohyalina brandii Giralt, van den Boom \& Elix sp. nov. Fig. 1

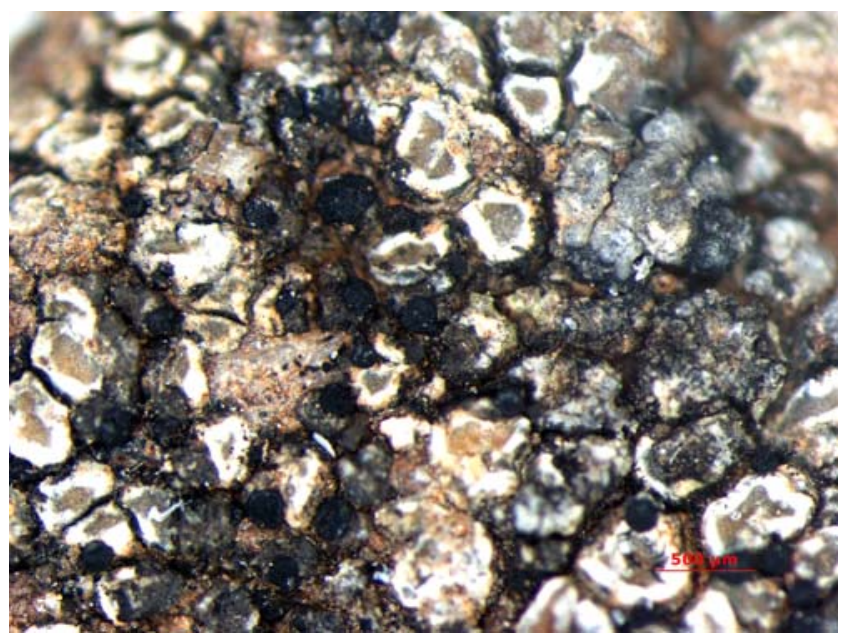

Fig. 1 Habit of Endohyalina brandii Giralt, van den Boom \& Elix, lichenicolous on Aspicilia intermutans (holotype). Scale bar $500 \mu \mathrm{m}$
Diagnosis Lichen lichenicola, Endohyalinae insularis similis, sed thallos lichenum Aspiciliae intermutantis incolens, thallo epikapylico bene evoluto, apotheciis $0.1-$ $0.2(-0.3) \mathrm{mm}$, sessilibus, hypothecio albido rubro-fusco, ascosporis $11-13(-14) \times 6-7(-7.5) \mu \mathrm{m}$, conidiis bacilliformibus, 3-4×1 $\mu \mathrm{m}$, diploicinum, isofulgidinum et caloploicinum continens.

Type Macaronesia, Canary Islands, Tenerife, near col in road Santiago-Masca, on Miocene volcanic rocks in open Euphorbia-Chamaecytisus vegetation, on Aspicilia intermutans, $900 \mathrm{~m}, 28^{\circ} 13.5^{\prime} \mathrm{N}, 16^{\circ} 49.4^{\prime} \mathrm{W}, 14.04 .1986, \mathrm{M}$. Brand 13680 (L-holotypus, isotype-hb. Brand).

Obligately lichenicolous on Aspicilia intermutans (Nyl.) Arnold. Thallus rarely absent (endokapylic), normally epikapylic, subsquamulose, areolate and inducing necrotic spots in the host. Areolae small, smooth, brown, rather thick, up to $150 \mu \mathrm{m}$, with abundant crystals insoluble in $\mathrm{K}$. Epinecral layer (8-)15-25 $\mu \mathrm{m}$; cortex 10-20 $\mu \mathrm{m}$, outermost external part brownish-green pigmented, $\mathrm{K}+$ pale violet; algal layer 80-100 $\mu \mathrm{m}$ thick, with chlorococcoid algae 10$18 \mu \mathrm{m}$ diam.; medulla absent to $20 \mu \mathrm{m}$ thick, I-. Apothecia lecideine, adnate to sessile, black, $0.1-0.2(-0.3) \mathrm{mm}$ diam., becoming hemispherical. Proper margin thin, not persistent. Disc plane but soon becoming convex. Excipulum proprium 30-50 $\mu \mathrm{m}$ wide. Hymenium 40-60 $\mu \mathrm{m}$ high, not inspersed. Hypothecium pale reddish brown 70-150 $\mu \mathrm{m}$ deep. Epihymenium dark brown. Apical cells of the paraphyses up to $6 \mu \mathrm{m}$ diam. Ascospores ellipsoid, Dirinaria-type $11-13(-14) \times 6-7(-7.5) \mu \mathrm{m}$, smooth at $\times 1,000$, spore ends \pm slightly paler, torus present or not. Inner wallthickenings angular (Dirinaria-type) in young ascospores, nearly disappearing (Milvina- or Physconia-type) in mature ascospores. Ascospore ontogeny of type B. Conidia bacilliform, $3-4 \times 1 \mu \mathrm{m}$.

Etymology The new species is named in honor of the collector, the lichenologist Maarten Brand, for his outstanding work on lichens and lichenicolous fungi in Europe and the Canary Islands.

Detailed chemical results Hb. Brand-13675: (1) Aspicilia intermutans + Endohyalina brandii: norstictic acid (major), connorstictic acid (trace), thuringione (minor), diploicin (minor), caloploicin (trace), isofulgidin (trace); (2) $A$. intermutans: norstictic acid (major), connorstictic acid (minor), thuringione (minor or trace).

Thus, E. brandii contains diploicin (minor), isofulgidin (trace) and caloploicin (trace).

Ecology and distribution This species is lichenicolous on $A$. intermutans and is only known from the type locality in Tenerife and from one additional locality in El Hierro. In the 
type locality, the lichen community growing on Miocene volcanic rocks includes Catillaria chalybeia (Borrer) A. Massal., Diploschistes bisporus (Bagl.) J. Steiner, Lecanora gangaleoides Nyl., Lecidella viridans (Flot.) Körb., Neofuscelia loxodes (Nyl.) Essl. s.l., N. verruculifera (Nyl.) Essl., Pertusaria corallina (L.) Arnold, Rhizocarpon geminatum Körb. and R. polycarpum (Hepp.) Th. Fr.

Discussion Endohyalina brandii is well characterized by the typically epikapylic, areolate, rather thick, brown thallus, the small $(0.1-0.3 \mathrm{~mm}$ diam.) lecideine apothecia, the absence of hymenial oil droplets, the pale hypothecium, the broad apical cells of the paraphyses and the ellipsoid ascospores. Apart from growing on the Lecanora rupicola agg. and usually lacking a thallus (endokapylic), E. insularis is distinguished by the larger (up to $0.7 \mathrm{~mm}$ diam.), initially immersed apothecia, the larger ascospores, and the darker hypothecium. Endohyalina interjecta, apparently not lichenicolous but closely associated with Rhizocarpon geographicum (L.) DC., has a dark brown hypothecium and narrower ascospores.

Endohyalina brandii, like E. interjecta, can be mistaken for Buellia badia (Fr.) A. Massal. because of its brown subsquamulose thallus and its lichenicolous (or apparently lichenicolous behavior). However, B. badia can be distinguished by the Buellia-ascospores developing with type A ontogeny. Previous records of $B$. badia could refer to both Endohyalina taxa.

Additional specimens examined Canary Islands, Tenerife, near col in road Santiago-Masca, on Miocene volcanic rocks in open Euphorbia-Chamaecytisus vegetation, on Aspicilia intermutans, $900 \mathrm{~m}, 28^{\circ} 13.5^{\prime} \mathrm{N}, 16^{\circ} 49.4^{\prime} \mathrm{W}, 14.04 .1986, \mathrm{M}$. Brand 13675 (topotype-hb. Brand). El Hierro, N of Frontera, $1 \mathrm{~km} \mathrm{SW}$ of El Matorral, small (secondary) road to Los Llanillos, Hoya de los Morotes, S side of road, field with small valley and volcanic outcrops, $55 \mathrm{~m}, 26.03 .2009$, P. \& B. van den Boom 41974 (hb v.d. Boom).

\section{Endohyalina diederichii Giralt, van den Boom \& Elix sp. nov. Fig. 2}

Diagnosis Lichen lichenicola, Endohyalinae ericinae var. ericinae similis, sed thallos lichenum Ramalinae incolens, thallo endokapylico vel epikapylico, debiliter evoluto, e granulis minutis; apotheciis minoribus et apotheciis juvenilibus in hospitis thallo immersis.

Type Macaronesia, Canary Islands, Lanzarote, SW of Haria, Valle del Malpaso NW slope in valley with volcanic outcrops and Pinus trees, on N sloping rock, $515 \mathrm{~m}, 29^{\circ}$ $07.8^{\prime \prime} \mathrm{N}, 13^{\circ} 31.2^{\prime \prime} \mathrm{W}, 07.03 .2003$, on Ramalina bourgeana

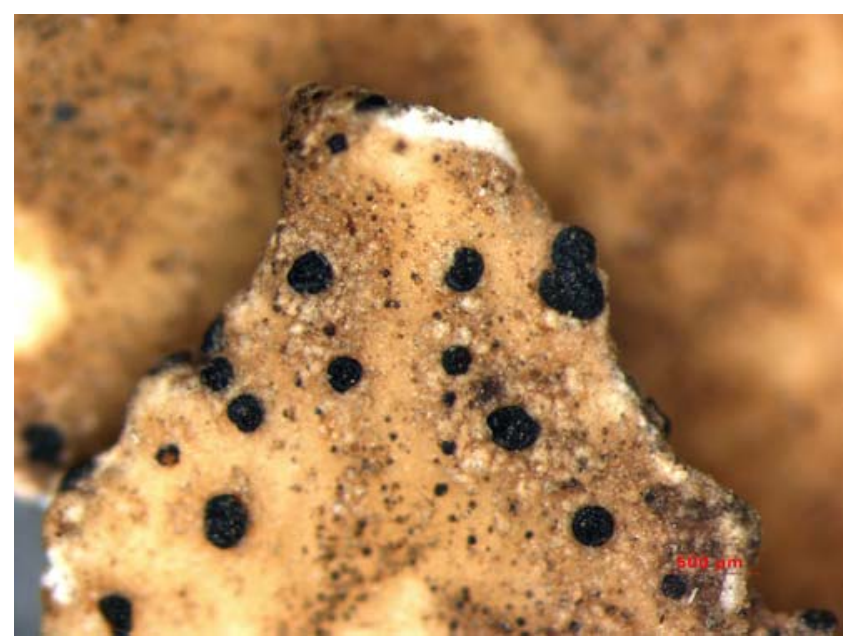

Fig. 2 Habit of Endohyalina diederichii Giralt, van den Boom \& Elix, lichenicolous on Ramalina bourgeana (holotype). Scale bar $500 \mu \mathrm{m}$

Mont. ex Nyl., P. \& B. van den Boom 30459 (HolotypeGZU, isotype-hb. van den Boom).

Obligately lichenicolous on Ramalina sp. pl. Thallus absent (endokapylic) to epikapylic, crustose, discontinuous, composed of minute, whitish to pale grayish granules, including crystals insoluble in $\mathrm{K}$. When well developed, the infection produces a brownish color of the cortex of the host. Algae chlorocccoid, 8-15 $\mu \mathrm{m}$ diam. Apothecia lecideine, immersed in the thallus of the host, becoming sessile and constricted at the base, $0.1-0.2(-0.3) \mathrm{mm}$ diam. Proper margin thick, prominent, persistent or not. Disc plane to subconvex, black. Excipulum proprium 30-40 $(-50) \mu \mathrm{m}$ wide. Hymenium colorless, inspersed with oil droplets, 50-60 $\mu \mathrm{m}$ high. Hypothecium brown, up to 100 deep. Apical cells of the paraphyses $2-4 \mu \mathrm{m}$ diam. Ascospores fusiform, of Dirinaria-type, (10-)12-15(-17) $\times$ 5-6(-7) $\mu \mathrm{m}$, smooth at $\times 1,000$, spore-ends paler, torus absent. Ascospore ontogeny of type B. Conidia not seen.

Etymology The new species is named in honor of the collector, the lichenologist Paul Diederich, for his exceptional contributions to the study of lichenicolous fungi worldwide.

Detailed chemical results $\mathrm{Hb}$. Boom-26191: (1) Ramalina sp. + Endohyalina diederichii: salazinic acid (major), protocetraric acid (major), convirensic acid (minor), usnic acid (minor), diploicin (minor), isofulgidin (trace), brialmontin 1 (trace); (2) R. sp.: salazinic acid (major), protocetraric acid (trace), norstictic acid (trace), consalazinic acid (minor), usnic acid (trace).

Type-Hb. Boom-30459: (1) Ramalina bourgeana $+E$. diederichii: salazinic acid (major), protocetraric acid (trace), consalazinic acid (minor), usnic acid (trace), diploicin (minor), fulgidin (trace), isofulgidin (minor), brialmontin 1 (trace), dechlorodiploicin (trace); (2) R. bourgeana: sala- 
zinic acid (major), protocetraric acid (trace), consalazinic acid (minor), usnic acid (trace).

Thus, E. diederichii contains diploicin (minor), isofulgidin (trace), fulgidin (trace or absent), dechlorodiploicin (trace or absent) and brialmontin 1 (trace).

Ecology and distribution E. diederichii has been found to be lichenicolous on Ramalina sp. pl. growing on rocks. It is known from the type locality in Lanzarote, from one locality in Fuerteventura, the eastern and drier Canary Islands, and from two additional localities, one in El Hierro and the other one in Tenerife. The type locality is rich in epiphytic lichens especially on branches of Pinus trees. The volcanic outcrops on which the new species was found are rather poor in lichens but the following have been recorded: Physcia adscendens (Fr.) H. Olivier, Ramalina decipiens Mont. and Roccella fusciformis (L.) DC.

Discussion Endohyalina diederichii is characterized by its whitish to pale gray, minutely granulose thallus, its hymenium densely inspersed with oil droplets, its weakly enlarged apical cells of the paraphyses, and its fusiform ascospores. It is closely related to E. ericina but differs in its endokapylic or epikapylic lichenicolous habit, its minutely granulose thallus and its smaller apothecia.

In the field, E. diederichii may readily be mistaken for Catillaria mediterranea Hafellner, a lichenicolous species which is common on Ramalina species in the Canary Islands. C. mediterranea has similarly sized, black lecideine apothecia. However, the ascospores are hyaline and $\mathrm{c}$. $6.5 \times 2.5 \mu \mathrm{m}$, and this species lacks secondary substances.

Additional specimens examined: Canary Islands, Fuerteventura, $\mathrm{N}$ of Betancuria, $\mathrm{S}$ side of road to mirador, near crossing with main-road, SW exposed rocky slope, $400 \mathrm{~m}$ from entrance along path, $550 \mathrm{~m}, 28^{\circ} 26.2^{\prime} \mathrm{N}, 14^{\circ} 02.8^{\prime} \mathrm{W}$, 03.03.2001, P. \& B. v. d. Boom (hb. Boom-26191). El Hierro, SW of Valverde, along road HI-1 to Tiñor, mirador W of La Calderata, E exposed slope, with crumbling steep rock and steep vertical volcanic outcrops, including overhanging branches of Rumex lunaria, 800 m, 29.03.2009, P. \& B. van den Boom 42543 (hb v.d. Boom). Tenerife, Anaga, along main road from Las Mercedes to Chamorga, $0.5 \mathrm{~km}$ crossing with road to San Andrés, $28^{\circ} 32^{\prime} 45^{\prime \prime} \mathrm{N}, 16^{\circ} 13^{\prime \prime} \mathrm{W}$, $730 \mathrm{~m}$, over rocks on ridge along road, on Ramalina sp., 19.07.2007, P. Diederich 16515 \& D. Ertz (hb. Diederich).

Endohyalina ericina (Nyl.) Giralt, van den Boom \& Elix var. ericina, comb. nov.

Basionym Lecidea ericina Nyl., Flora 61: 452 (1878); Buellia ericina (Nyl.) Jatta, Syll. Lich. Ital.: 397 (1900);
Rinodina ericina (Nyl.) Giralt, Lichenologist 32: 312 (2000). Type: France, Corsica, Ajaccio, super corticem Ericae arboreae, 1878, Norrlin (H-holotype!).

Synonym Rinodina madeirensis Kalb \& Hafellner, Herzogia 9: 87 (1992). Type: Macaronesia, Madeira, Levada of Queimadas, near Caldero Verde, on old Cryptomeria, 900 m, 1990, K. Kalb \& A. Kalb (hb. Kalb 23731-holotype!).

New synonym Endohyalina rappii (Imshaug ex R.C. Harris) Marbach, Biblioth. Lichenol. 74: 205 (2000); Buellia rappii Imshaug ex R.C. Harris, Some Florida lichens: 74 (1990). Type: U.S.A., Florida, Franklin County, along US 98 ca. 5 mi E of jet with Fla. Hwy 65, W of town of Carrabelle; oak scrub near Gulf of Mexico, 01.12.1988, R.C. Harris 23166 (NY-holotype!).

Further information and illustrations Kalb and Hafellner (1992, Abb. 2: 57; Abb. 17-18: 102) and Giralt and Matzer (1994, Fig. C: 324), sub R. madeirensis; Imshaug (1951), Hale and Culberson (1956) and Harris (1988, 1990), sub Buellia rappii; Giralt (2000, 2001, plate XVIII C: 160) and van den Boom et al. (2009, Fig. 3: 433), sub Rinodina ericina; Marbach (2000, Abb. 93 \& 94: 206-207, sub. Endohyalina rappii).

Thallus autonomous, composed of discrete to continuous verrucae, whitish to pale grayish. Apothecia lecideine, sessile, $0.2-0.5(-0.7) \mathrm{mm}$ diam. Proper margin thick, persistent. Disc plane to subconvex. Excipulum proprium 30-45 $\mu \mathrm{m}$ wide. Hymenium colorless, 50-70 $\mu \mathrm{m}$ high, usually inspersed with numerous oil droplets. Hypothecium dark brown. Apical cells of the paraphyses 3-4(-5) $\mu \mathrm{m}$ wide. Ascospores fusiform, Dirinaria-type, (10-)11-13 $(-18) \times(4.5-) 5-6(-6.5) \mu \mathrm{m}$, smooth at $\times 1,000$, spore-ends paler, torus absent. Ascospore ontogeny of type B. Conidia bacilliform, (5-)6-7×1 $\mu \mathrm{m}$.

Chemistry Thallus $\mathrm{K}+$ yellow, $\mathrm{PD}+$ faintly yellow. Containing diploicin (major), atranorin (minor), isofulgidin (minor), fulgidin (trace) and one additional unknown substance (Giralt 2000). According to Marbach (2000), E. rappii contains atranorin and diploicin.

Ecology and distribution Endohyalina ericina is an oceanic species, occurring locally along the Atlantic coast of Europe as far north as Ireland and of America as far south as Brazil. It is widespread in Macaronesia but in the Mediterranean region it is known only from Corsica (type locality).

Discussion Of the species treated, E. ericina is very similar to $E$. diederichii but differs in its better developed, nonlichenicolous thallus which sometimes develop soralia (var. 
boomii). Both taxa have whitish to pale grayish thalli, inspersed hymenia, weakly enlarged apical cells of the paraphyses and fusiform ascospores.

Additional specimens examined U.S.A.: Florida, Lake County, Ocala National Forest, N of Forest Serv. Rd. 552, $0.2 \mathrm{mi}$ E of Forest Serv. Rd. 544, $1.1 \mathrm{mi}$ E of Co. Rd. 445, ca. $2 \mathrm{mi} \mathrm{W}$ of Alexander Springs; dwarf oak scrub, 1988, W.R. Buck 16782 (NY). Duval County, Big Talbot Island State Park, ca. $0.7 \mathrm{mi} \mathrm{S}$ of northern boundary of Park; coastal oak scrub; on branch of Lyonia ferruginea, 1987, W.R. Buck 15516 (NY). Duval County, Big Talbot Island State Park, along trail to "scrubby Bluff", $1.1 \mathrm{mi}$ from N end of park, 2.2 mi from $\mathrm{S}$ end of park; oak scrub grading into coastal hammock, on Quercus, 1988, R.C. Harris 23920 \& W.R. Buck 16941 (NY). BRAZIL: São Paulo: Municipio Moji Guaçu, Bairro Martinho Prado Jr., Reserva Biológica de Moji-Guaçu, Cerradao, 560 m, 20.08.1995, B. Marbach \& M. Marcellii 1128 (hb. Kalb). Praia de Peruibe bei Itanhaém, in einer Mangrove, $1 \mathrm{~m}, 1978$, K. Kalb 28656 \& G. Plöbst (hb. Kalb). In einer dichten Mangrove, 2 m, 1980, K. Kalb 28657, 28658, 28661 (hb. Kalb). Ilha Comprida von Cananeia, in einer Mangrove, $1 \mathrm{~m}, 1979$, K. Kalb 28660 (hb. Kalb). Rio Itaguaré, etwa $20 \mathrm{~km}$ E von Bertioga, in einer Mangrove an Laguncularia racemosa, 1 m, 1980, K. Kalb 28659, 28662 (hb. Kalb).

See also specimens examined in Giralt and Matzer (1994, under Rinodina madeirensis) and in Giralt (2000, under R. ericina).

\section{Endohyalina ericina Giralt, van den Boom \& Elix var.} boomii (Giralt) Giralt, van den Boom \& Elix, comb. nov.

Basionym Rinodina ericina var. boomii, Lichenologist 32: 313 (2000). Type: Portugal, Algarve, N of Albufeira, $1 \mathrm{~km} \mathrm{~N}$ of Alte, E slope along path, orchard with Ceratonia, Olea, Prunus dulcis and calcareous outcrops, 400 m, on Ceratonia siliqua, 1993, P. v.d Boom (BCN-van den Boom 14934 holotype!).

Further information and illustrations Giralt (2000, 2001).

Description This variety differs from E. ericina var. ericina by the presence of discrete, bluish-gray soralia, up to $0.5 \mathrm{~mm}$ diam.

Ecology and distribution At present, known only from two localities in southern Portugal. It seems to be a maritime taxon because in both sites it was found growing close to the sea.

Specimens examined See Giralt (2000, 2001).
Endohyalina insularis (Arnold) Giralt, van den Boom \& Elix, comb. nov.

Basionym Buellia saxatilis f. insularis Arnold, Verhandl. Zool.-Bot. Ges. Wien 46: 119 (1896); Rinodina insularis (Arnold) Hafellner, Beih. Nova Hedwigia 62: 87 (1979). Type: South Tirol, Plan, 1895, Arnold (M-holotype, not seen).

Further information and illustrations Hafellner (1979, Abb. 8: 89), Mayrhofer and Poelt (1979), Mayrhofer (1984), Triebel et al. (1991), Rambold and Triebel (1992), Nimis (1993), Matzer et al. (1994), Rambold et al. (1994), Giralt and Llimona (1997, Fig. 1E: 176), Giralt (2000, 2001), Mayrhofer and Moberg (2002: 104), Hafellner (2004), Mayrhofer and Lambauer (2004), Sheard (2004), Kaschik (2006, Fig. 83: 126).

This species is obligately lichenicolous on the Lecanora rupicola agg. Thallus endokapylic to very rarely epikapylic and then visible only around the apothecia, brown. Apothecia lecideine, immersed in the thallus of the host to adnate, $0.2-0.4(-0.7) \mathrm{mm}$ diam. Proper margin thin, becoming excluded. Excipulum proprium $40-60 \mu \mathrm{m}$ wide. Hymenium 50-70(-80) $\mu \mathrm{m}$ high, not inspersed. Hypothecium dark brown, with stipe. Apical cells of the paraphyses up to $5(-6) \mu \mathrm{m}$, with a brown cap. Asci Bacidia-type. Ascospores ellipsoid, Dirinaria-type, 11-15(-17) $\times 5.5-7.5$ (-9) $\mu \mathrm{m}$, microrugulate at $\times 1,000$ spore-ends paler, torus absent. Ascospore ontogeny of type B. Conidia not seen.

Detailed chemical results BCN-hb. Barbero-180: (1) Lecanora rupicola agg. + Endohyalina insularis: atranorin (minor), chloroatranorin (minor), diploicin (major), isofulgidin (trace), fulgidin (trace); (2) L. rupicola: atranorin (major), chloroatranorin (minor).

BCN-hb. Barbero-181: (1) L. rupicola + E. insularis: atranorin (minor), chloroatranorin (minor), diploicin (major), isofulgidin (trace), dechlorodiploicin (trace), fulgidin (trace); (2) L. rupicola: atranorin (major), chloroatranorin (minor).

Hb. Boom-20602: (1) L. rupicola + E. insularis: atranorin (major), chloroatranorin (minor), caloploicin (minor), diploicin (trace); (2) L. rupicola: atranorin (major), chloroatranorin (minor).

BCN-hb. Barbero-179: (1) L. rupicola + E. insularis: atranorin (minor), chloroatranorin (minor), diploicin (major), isofulgidin (trace), dechlorodiploicin (trace), fulgidin (trace).

Thus, E. insularis contains diploicin (usually as major), isofulgidin (trace), fulgidin (trace), dechlorodiploicin (trace or absent) and caloploicin (minor or absent). This is the first report of the secondary chemistry of this species.

Ecology and distribution Endohyalina insularis is obligately lichenicolous on species of the Lecanora rupicola agg. 
and is distributed world-wide. It has been reported from northern to southern Europe (Mayrhofer 1984, Abb. 53: 426), North America (Sheard 2004: 478) Australasia, South America (Kaschik 2006, figs. 84, 85 \& 86: 127-128) and Macaronesia. Its distribution is coincident with that of Diploicia canescens (Kalb and Elix 2007).

Discussion Endohyalina insularis is characterized by the typically endokapylic thallus, the large apothecia immersed in the thallus of the host, the lack of hymenial oil droplets, the large apical cells of the paraphyses, the dark hypothecium and the ellipsoid ascospores (see under E. brandii and E. interjecta).

Specimens examined FRANCE: Ardennes, Chooz, rochers de Petit-Chooz sur la rive droite de la Meuse, face au pont, IFBL: J5.35, affleurement de roches de 1'Emsien supérieur (Grauwacke de Hierges), sur Lecanora rupicola s. str., 30.04.1999, P. Diederich 16367 (hb. P. Diederich). SPAIN: Catalunya: Barcelona, Maresme, Dosrius, Can Massuet-El Far, 375 m, 28.02.1987, M. Barbero 179, 180, 181, 192, 193 (BCN). Girona, 1,3 km NE of Meranges, $0.5 \mathrm{~km}$ further from crossing to Malniu/Feixa, S sloping Pinus forest with shaded acid outcrops, $200 \mathrm{~m}, 42^{\circ} 27.30^{\prime \prime} \mathrm{N}$, $1^{\circ} 48.00^{\prime \prime} \mathrm{W}, 14.08 .1998$, P. \& B. v.d. Boom 20602 (hb. v.d. Boom).

See also Giralt (2001).

\section{Endohyalina interjecta (Müll. Arg.) Giralt, comb. nov.}

Basionym Buellia interjecta Müll. Arg. Flora 55: 499 (1872); Lecidea interjecta (Müll. Arg.) Stizenb., Ber. Thät St. Gall. Naturw. Ges. 1880-81: 481 (1882); Rinodina interjecta (Müll. Arg.) H. Mayrhofer, Sheid. \& Sheard, Nord. J. Bot. 12: 452 (1992).

Type France, Dept. Savoie, Salève near Geneva, above Pas de l'Échelle, 30.08.1872, J. Müller (G-holotype!).

Further information and illustrations Mayrhofer et al. (1992, Fig. 2: 452).

Thallus autonomous, areolate to subsquamulose, thick, brown. Apothecia lecideine, subimmersed to adnate, 0.2$0.5 \mathrm{~mm}$ diam.; medulla I-. Proper margin thin, not persistent. Disc convex to hemispherical, black. Excipulum proprium 10-20 $\mu \mathrm{m}$ wide. Hymenium $60-80 \mu \mathrm{m}$ high, not inspersed. Hypothecium brown with stipe. Apical cells of the paraphyses (4-)5-6 $\mu \mathrm{m}$ diam. Ascospores of Dirinariatype, $10-12(-14) \times 4.5-5.5 \mu \mathrm{m}$, microrugulate at $\times 1,000$, spore-ends paler, torus developed; ascospore ontogeny of type B. Conidia bacilliform, 5-6×1 $\mu \mathrm{m}$.
Chemistry At present, this species is only known from the type collection and there is insufficient material for chemical analyses. Nevertheless, crystals are visible in the cortex and especially in the medulla under polarized light. These crystals are of two forms: very small crystals which dissolve in $\mathrm{K}$ to give a yellowish solution (probably atranorin) and become yellow with PD; and larger crystals which neither are soluble in $\mathrm{K}$ nor give a yellow color in PD (diploicin?).

Ecology and distribution Only known from the type locality, in the mountains near Genève (France), growing on granitic boulders among thalli of Rhizocarpon geographicum.

Discussion The ascospores of the type material develop with type B ontogeny, a feature not mentioned in the excellent description of Rinodina interjecta given by Mayrhofer et al. (1992). This character clearly indicates that this species belongs to Endohyalina as described above.

Endohyalina interjecta is characterized by the autonomous, brown, rather thick, subsquamulose thallus, the subimmersed to adnate apothecia, the hymenium lacking oil droplets, the large apical cells of the paraphyses, and the ellipsoid ascospores with a torus. Among the other species of Endohyalina, it is close to E. brandii and E. insularis, but the latter species differs in their obligately lichenicolous habit and wider ascospores.

\section{Endohyalina kalbii (Giralt \& Matzer) Giralt, van den Boom \& Elix, comb. nov.}

Basionym Rinodina kalbii Giralt \& Matzer, Lichenologist 26: 328 (1994). Type: Italy, Sardinia, Sassari, Badesi Mare, on littoral sand dunes, $10 \mathrm{~m}$, on Tamarix, 1986, J. Poelt \& P.L. Nimis (TSB-holotype!).

Further information and illustrations Giralt and Matzer (1994, Figs. 1A, 2B \& 5: 320, 322 \& 329), Rambold et al. (1994, Fig. 1: 34), Giralt et al. (1996), Giralt (2000).

Thallus autonomous, crustose, continuous, smooth, brownish, lacking crystals (polarized light). Apothecia lecideine, adnate to sessile, up to $1 \mathrm{~mm}$ diam. Proper margin thick, persistent. Disc concave to subconvex, black. Excipulum proprium 40-50(-70) $\mu \mathrm{m}$ wide. Hymenium 60 $80 \mu \mathrm{m}$ high, not inspersed. Hypothecium pale to dark reddish brown. Apical cells of the paraphyses up to $6 \mu \mathrm{m}$ diam. Asci of Bacidia-type. Ascospores of Dirinaria-type, with lumina angular when young, becoming rounded when mature (=Pachysporaria-type), (11-)12-16×(5-)6-8 $\mu \mathrm{m}$, smooth to microrugulate at $\times 1,000$, torus not or poorly developed. Ascospore ontogeny of type B. Conidia bacilliform, $5-6 \times 1 \mu \mathrm{m}$. 
Chemistry The two specimens analysed by HPLC contain: secalonic acid A (major), and an unknown secalonic acid (trace). These substances are present in the excipulum (crystals under polarized light) and must be responsible of the $\mathrm{K}+$ yellow reaction of the excipulum proprium, already mentioned in Giralt and Matzer (1994) and Giralt (2001).

The secondary chemistry of E. kalbii has not been reported previously.

Ecology and distribution This is a maritime species with a Mediterranean-South Atlantic distribution, including Macaronesia. It usually occurs in the salt-spray belt growing on old, rough bark associated with \pm nitrophilous species.

Discussion Endohyalina kalbii differs from the other species of Endohyalina by its alternative chemistry, as it contains the bisxanthone secalonic A rather than diploicin (and related substances). An additional feature found only in this species is the lumina of its Dirinaria-type ascospores that become rounded and Pachysporaria-type at maturity. Despite these differences, the other diagnostic characters of E. kalbii fit within the concept of the genus Endohyalina established here.

Additional specimens examined SPAIN: Balearic Islands, Menorca, Ciutadella, Cala Morell, near Ses Coves, 30 m, on Pinus halepensis and Juniperus phoenicea, 1.07.1993, Boqueras et al. (BCN, three specimens). PORTUGAL: Algarve, WNW of Sagres, Cabo de São Vicente, coastal area with low calcareous outcrops and mixed shrubs, on Juniperus phoenicea, 28.04.2004, P. \& B. van den Boom 32394 (hb. v.d. Boom).

See also the specimens examined listed in the several references from Giralt given above.

\section{Excluded species}

Buellia circumpallida H. Magn. Ark. Bot. 3(10): 379 (1954)

Basionym Endohyalina circumpallida (H. Magn.) Marbach, Biblioth. Lichenol. 74: 202 (2000). Type: U.S.A., Hawaii, Hanalei, on smooth bark, 1910 (not seen).

Further information and illustrations Tuckerman (1888, sub Buellia amphidextra); Magnusson (1954), Imshaug (1951), Hale and Culberson (1956) and Harris (1988, Fig. 1-2: 41), sub B. amphidexia; Marbach (2000, Abb. 91 \& 92: 204, sub Endohyalina circumpallida).

Discussion Buellia circumpallida lacks the combination of main diagnostic characters described above for the genus Endohyalina (namely the aethalea-type excipulum; Diri- naria-type ascospores; ontogeny type B; diploicin). Like many other species of Buellia s. lat., it possesses a crustose thallus which contains atranorin, has lecideine apothecia, a brown hypothecium, Bacidia-type asci and ascospores without inner wall thickenings, developing after an ontogeny of type A. For these reasons it is retained in Buellia.

As the specific name describes, the excipulum proprium of B. circumpallida is very characteristic and unknown elsewhere in Physciaceae. It is clearly structured in three different parts somewhat like a ladder. The outermost part $(10-15 \mu \mathrm{m})$ is brown pigmented, composed of hyphae with \pm swollen cells. The central part (up to $40 \mu \mathrm{m}$ wide) is colorless, composed of relatively few, thick-walled hyphae, up to $3 \mu \mathrm{m}$ wide, embedded in an amorphous matrix (I-) which includes oil droplets. Finally, the innermost part (10$15 \mu \mathrm{m}$ wide) is also dark brown pigmented but has hyphae radiating from the dark hypothecium. The few colorless hyphae of the central part are like the steps of the ladder that connect the brown outermost and innermost parts. No crystals are observed in the excipulum under polarized light.

In fact, the generic name Endohyalina given by Marbach (2000) refers better to this species than to E. ericina (=E rappii), the species he chose as the generic type. Another interesting character of Buellia circumpallida is the presence of a reddish pigment ( $\mathrm{K}+$ yellow-orange) between the paraphyses tips at the epihymenium level. Further, the ascospores are very thin walled and pale brown pigmented, similar to those of Buellia schaereri De Not. or Rinodinella H. Mayrhofer \& Poelt species.

Specimens examined BRAZIL: Mato Grosso, zwischen Jaciara und Sao Vicente, etwa $100 \mathrm{~km}$ ostsüdöstlich von Cuiba, in einem Cerrado, 750 m, 2.07.1980, K. Kalb 28665 (hb. Kalb). São Paulo, Rio Itaguaré, etwa 20 km östlich von Bertioga; in einer Mangrove an Laguncularia racemosa, 1 m, 13.04.1980, K. Kalb 28668, 28669 (hb. Kalb). Ilha de Santo Amaro, kurz vor Bertioga, etwa $20 \mathrm{~km}$ nordöstlich von Santos; in einer Mangrove, $1 \mathrm{~m}, 21.10 .1978$, K. Kalb 28667 \& G. Plöbst (hb. Kalb); Praia de Peruibe bei Itanhaém; in einer dicten Mangrove, 2 m, 09.07.1980, K. Kalb 28664 (hb. Kalb). Praia Grande südlich von São Paulo, in einer Mangrove, 2 m, 18.12.1978, K. Kalb 28666 \& D. Hannak (hb. Kalb). MASKARENEN: La Réunion, Forêt de Bébour, wenige Kilometer NW von la Plaine-desPalmistes. Sentier Botanique. Tropischer Berg-Primärwald, $21^{\circ} 08^{\prime} \mathrm{S}, 55^{\circ} 35^{\prime} 30^{\prime \prime} \mathrm{E}, 1,300 \mathrm{~m}, 31.08 .1991$, K. \& A. Kalb 25201 (hb. Kalb).

Acknowledgements The authors are indebted to $\mathrm{M}$. Brand, P. Diederich, K. Kalb, and the curators of BCN, G, and NY for the loan of material used in this study, and to H. Sipman and P. Diederich for their valuable comments on the manuscript and for correcting the 
Latin diagnoses. The first author thanks the "Comissionat per a la Recerca" (Catalan Government) for financial support.

\section{References}

Awasthi DD (1975) A monograph of the lichen genus Dirinaria. Bibl Lichenol 2:1-108

Bungartz F, Elix JA, Nash TH III (2004) The genus Buellia Sensu Lato in the Greater Sonoran Desert Region: saxicolous species with one-septate ascospores containing xanthones. Bryologist 107:459-479

Bungartz F, Nordin A, Grube U (2007) Buellia De Not. In: Nash TH III, Gries C, Bungartz F (eds) Lichen flora of the Greater Sonoran Desert Region, Vol. 3. Lichens Unlimited, Arizona State University, Tempe, pp 113-179

Crespo A, Blanco O, Llimona X, Fenencová Z, Hawksworth DL (2004) Coscinocladium, and overlooked endemic and monotypic Mediterranean lichen genus of the Physciaceae, reinstated by molecular phylogenetic analysis. Taxon 53:405-414

Elix JA, Jenkins GA, Lumbsch HT (1988) Chemical variation in the lichen genus Diploicia (Ascomycotina). Mycotaxon 33:457466

Elix JA, Giralt M, Wardlaw JH (2003) New chloro-depsides from the lichen Dimelaena radiata. Bibl Lichenol 86:1-7

Gams W (2004) Report of the Committee for fungi: 11. Taxon 53:1067-1069

Giralt M (2000) The identity of Buellia ericina and its generic position. Lichenologist 32:309-316

Giralt M (2001) The lichen genera Rinodina and Rinodinella (lichenized Ascomycetes, Physciaceae) in the Iberian Peninsula. Bibl Lichenol 79:1-160

Giralt M, Llimona X (1997) The saxicolous species of the genera Rinodina and Rinodinella lacking spot test reactions in the Iberian Peninsula. Mycotaxon 62:175-224

Giralt M, Matzer M (1994) The corticolous species of the genus Rinodina with biatorine or lecideine apothecia in southern Europe and Macaronesia. Lichenologist 26:319-332

Giralt M, Nordin A (2002) Buellia triseptata in the Iberian Peninsula. Lichenologist 34:89-94

Giralt M, van den Boom PPG, Boqueras M (1996) Nuevas localidades para cinco especies del género Rinodina recientemente descritas o muy poco citadas. Folia Bot Misc 10:5-9

Giralt M, Paz-Bermúdez G, Elix JA (2009) New data on Sculptolumina japonica (Physciaceae). Bryologist 102:397-407

Hafellner J (1979) Karschia. Revision einer Sammelgattung an der Grenze von lichenisierten und nichlichenisierten Ascomyceten. Beihefte zur Nova Hedwigia 62:1-248

Hafellner J (2004) A further evolutionary lineage to lichenicolous growth in Physciaceae (Lecanorales). Bibl Lichenol 88:175186

Hale ME Jr, Culberson WL (1956) A checklist of the lichens of the United States, Canada, and Alaska. Castanea 21:73-105

Harris RC (1988) Buellia in north and central Florida or the virtues and rewards of collecting. Evansia 5:37-45

Harris RC (1990) Some Florida lichens. Published by the author, Bronx, NY

Helms G, Friedl T, Rambold G (2003) Phylogenetic relationships of the Physciaceae inferred from rDNA sequence data and selected phenotypic characters. Mycologia 95:1078-1099

Imshaug HA (1951) The lichen-forming species of the genus Buellia occurring in the United States and Canada. DPhil Thesis, University of Michigan

Kalb K, Hafellner J (1992) Bemerkenswerte Flechten und lichenicole Pilze von der Insel Madeira. Herzogia 9:45-102
Kalb K, Elix J (2007) Diploicia A. Massal. In: Nash TH III, Gries C, Bungartz F (eds) Lichen flora of the Greater Sonoran Desert Region, Vol. 3. Lichens Unlimited, Arizona State University, Tempe, pp 226-227

Kaschik M (2006) Taxonomic studies on saxicolous species of the genus Rinodina (lichenized Ascomycetes, Physciaceae) in the Southern Hemisphere with emphasis in Australia and New Zealand. Bibl Lichenol 93:1-162

Magnusson AH (1954) A catalogue of the Hawaiian lichens. Arkiv Bot Ser 2,3(10):223-402

Marbach B (2000) Corticole und lignicole Arten der Flechtengattung Buellia sensu lato in den Subtropen und Tropen. Bibl Lichenol 74:1-384

Matzer M, Mayrhofer H, Rambold G (1997) Diploicia africana comb. nov. (lichenized Ascomycetes, Physciaceae), an endemic species from the Cape Province (South Africa). Nord J Bot $17: 433-438$

Matzer M, Mayrhofer H, Sattler J, Clerc Ph (1994) Rinodina canariensis (lichenized Ascomycetes, Physciaceae), a new species parasitic on crustose lichens in Macaronesia and the Mediterranean region. Nord J Bot 104:105-111

Mayrhofer H (1984) Die saxicolen Arten der Flechtengattungen Rinodina und Rinodinella in der Alten Welt. J Hattori Bot Lab 55:327-493

Mayrhofer H, Lambauer M (2004) Additional lichen records from New Zealand 41. Saxicolous and lichenicolous species of the genus Rinodina. Australasian Lichenology 54:28-32

Mayrhofer H, Moberg R (2002) Rinodina. Nordic Lichen Flora 2:4169

Mayrhofer H, Poelt J (1979) Die saxicolen Arten der Flechtengattung Rinodina in Europa. Bibl Lichenol 12:1-186

Mayrhofer H, Scheidegger C, Sheard JW (1992) On the taxonomy of five saxicolous species of the genus Rinodina (lichenized Ascomycetes). Nord J Bot 12:451-459

Nimis PL (1993) The lichens of Italy. An annotated catalogue. Monografia XII. Torino, Museo Regionale di Scienze Naturali

Nordin A (2000) Taxonomy and phylogeny of Buellia species with pluriseptate spores (Lecanorales, Ascomycotina). Symbolae Botanicae Upsaliensis 33:1-117

Poelt J, Vězda A (1984) Rhizocarpon inimicum spec. nov. eine weitere parasitische Flechte auf Lecanora rupicola spec. coll. Herzogia 6:467-480

Rambold G, Triebel D (1992) The Inter-lecanoralean Associations. Bibl Lichenol 48:1-201

Rambold G, Mayrhofer H, Matzer M (1994) On the ascus types in the Physciaceae (Lecanorales). Plant Syst Evol 192:31-40

Rico VJ, Giralt M, Calatayud V (2003) Buellia tesserata and Dimelaena radiata, two closely related species. Lichenologist 35:117-124

Scheidegger C (1993) A revision of European saxicolous species of the genus Buellia de Not. and formerly included genera. Lichenologist 25:315-364

Sheard JW (2004) Rinodina (Ach.) Gray. In: Nash TH III, Ryan BD, Diederich P, Gries C, Bungartz F (eds) Lichen flora of the Greater Sonoran Desert Region, vol. 2. Lichens Unlimited, Arizona State University, Tempe, pp 467-502

Sheard JW, Lendemer JC, Tripp EA (2008) Buellia japonica (Physciaceae), a new lichen record for North America. Bryologist 111:124-127

Triebel D, Rambold G, Nash TH III (1991) On lichenicolous fungi from continental North America. Mycotaxon 42:263296

Trinkaus U, Mayrhofer H (2000) Revision der Buellia epigaeaGruppe (lichenisierte Ascomyceten, Physciaceae). I. Die Arten der Nordhemisphäre. Nova Hedwig 71:271-314 
Trinkaus U, Mayrhofer H, Elix JA (2001) Revision of the Buellia epigaea-group (lichenized ascomycetes, Physciaceae) 2. The species in Australia. Lichenologist 33:47-62

Tuckerman E (1888) A synopsis of the North American lichens; Part II, comprising the Lecidei, and (in part) the Graphidacei. AnthonyNew Bedford van den Boom PPG, Giralt M, Etayo J (2009) Notes on the lichen genus Rinodina (Physciaceae, Ascomycota) from the Canary Islands. Nova Hedwig 88:423-440

Wedin M, Baloch E, Grube M (2002) Parsimony analyses of mtSSU and nITS rDNA sequences reveal the natural relationships of the lichen families Physciaceae and Caliciaceae. Taxon 51:655-660 